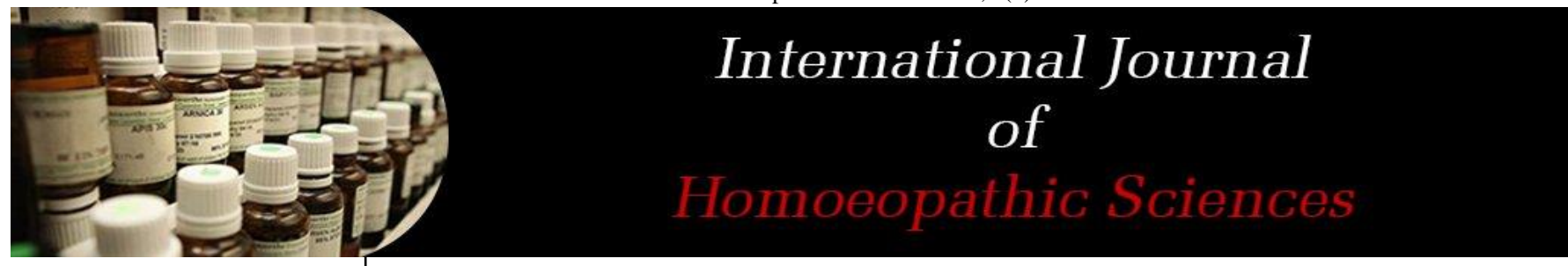

E-ISSN: 2616-4493 P-ISSN: 2616-4485 www.homoeopathicjournal.com IJHS 2021; 5(2): 162-165 Received: 15-02-2021 Accepted: 17-03-2021

Dr. Dhanaraj Kumar Rana MD (Hom), MPA, MAPC, CYAGC. Research Officer/S-1, Assistant Professor, Dept. of Psychiatry, National Homoeopathy Research Institute in Mental Health, Kottayam, Kerala, India

Dr. Jaseela Villan Post Graduate Trainee, Dept of Psychiatry, NHRIMH, Kottayam, Kerala India
Corresponding Author: Dr. Dhanaraj Kumar Rana MD (Hom), MPA, MAPC, CYAGC. Research Officer/S-1, Assistant Professor, Dept. of Psychiatry, National Homoeopathy Research Institute in Menta Health, Kottayam, Kerala, India

\section{Homoeopathic approach in the management of warts: A case report}

\author{
Dr. Dhanaraj Kumar Rana and Dr. Jaseela Villan
}

DOI: https://doi.org/10.33545/26164485.2021.v5.i2c.378

\begin{abstract}
Warts are common benign epithelial hyperplasia due to infection with human papilloma viruses (HPV) Papilloma viruses are double stranded DNA viruses of the PAPOVA class with host and tissue specificity. They infect squamous epithelia of skin and mucous membrane causing cell proliferation. Currently, more than 150 types of HPV have been identified. Certain HPV types tend to infect skin at particular anatomical sites; however, warts of any HPV type may occur at any site. Here we present a case of 23yearold male with complaints of multiple warts on dorsum of right foot. After detailed case taking and repertorization, Medorrhinum was given as similimum. Patient reported complete disappearance of warts within a period of 3 months. The aim of article is to show the scope of homoeopathy in the management of warts.
\end{abstract}

Keywords: Warts, homoeopathy, human papilloma virus, medorrhinum

\section{Introduction}

Cutaneous warts are benign, spontaneously regressing, epithelial tumors differing in clinical morphology and histological pattern depending on the inducing human papilloma virus (HPV)-types. Distinct HPVs, responsible for cutaneous warts are preferentially associated with specific types of warts. At present, over 90 genotypes have been characterized, of these, at least 15 types were found associated with cutaneous warts, and 19 with cutaneous warts in epidermodysplasia verruciformis (EV); however, the morphological and histologic criteria for recognition of distinct wart types are not universally accepted. HPVs are widespread in nature. The prevalence of warts is as high as up to $20 \%$ of the population, and most persons have warts at one time or other; however, they occur more frequently in children and adolescents $12-16$ years of age ${ }^{[1]}$.

The primary clinical manifestations of HPV infection include common warts, genital warts, flat warts, and deep palmoplantar warts (myrmecia). Less common manifestations of HPV infection include focal epithelial hyperplasia (Heck disease), epidermodysplasia verruciformis, and plantar cysts. Warts are transmitted by direct or indirect contact, and predisposing factors include disruption to the normal epithelial barrier. Each kind of wart can grow on any part of the body but is more commonly associated with specific areas of the body such as the hands, face, extremities, genitalia or feet ${ }^{[2]}$.

HPV infect squamous epithelia of the skin and mucous membrane causing cell proliferation. The virus infects the basal layer of the epithelium, but viral replication takes place in fully differentiated cells of upper stratum spinosum and stratum granulosum. After initial infection, HPV may persist in a latent form and may be reactivated later leading to recurrence of lesion ${ }^{[3]}$.

\section{Pathophisiology}

HPV, incubation period usually 3 to 4 months, with a range of 1 month to 2 years. HPV affect all type of squamous epithelium and the gross and histologic appearance of individual lesions vary with the site of infection and type of virus. The replication of HPV begins with the infection of basal cells. A pathognomonic feature is the presence of large vacuolated cells with round, deeply basophilic nuclei in the upper stratum malpighi and granular layer. Some of these contain intranuclear and cytoplasmic eosinophilic inclusions ${ }^{[4,5]}$. 


\section{Histopathology \\ Common wart (Verrucca vulgaris)}

Histopathologic features include acanthosis, digitated epidermal hyperplasia, papillomatosis, compact orthokeratosis, hypergranulosis, tortuous capillaries within the dermal papillae, and vertical tiers of parakeratotic cells with red blood cells entrapped above the tips of the digitations. Elongated rete ridges may point radially towards the center of the lesion. In the granular layer, cells infected with HPV have coarse keratohyalin granules and vacuoles surrounding wrinkled-appearing nuclei. Koilocytic cells are pathognomonic.

\section{Butcher's}

Butcher's warts have acanthosis, hyperkeratosis, and papillomatosis. Small vacuolized cells are seen, and centrally located shrunken nuclei may be identified in clusters within the granular layer rete ridges.

\section{Filiform}

Filiform warts appear similar to common warts, but they may have prominent papillomatosis.

\section{Focal Epithelial Hyperplasia (Heck disease)}

Focal epithelial hyperplasia is characterized by acanthosis, blunting, hyperplastic mucosa with thin parakeratotic stratum corneum, anastomosis of rete ridges, and whiteness of epidermal cells due to intracellular edema. Some may have prominent keratohyalin granules, and vacuolated cells may be present.

\section{Deep Palmoplantar}

Deep palmoplantar warts are similar to common warts except the lesion lies deep to the plane of the skin surface. The endophytic epidermal growth has the distinctive feature of polygonal, refractile-appearing, eosinophilic, cytoplasmic inclusions made up of keratin filaments, forming ringlike structures. Basophilic parakeratotic cells loaded with virions and basophilic nuclear inclusions and may be in the upper layers of the epidermis.

\section{Flat}

Flat warts are similar to common warts in light microscopy. Cells with prominent perinuclear vacuolization around pyknotic, basophilic, centrally located nuclei can be in the granular layer. These are referred to as "owl's eye cells."

\section{Cystic}

A cyst wart is filled with horny material. The wall is composed of basal, granular, and squamous cells. Many epithelial cells have large nuclei and clear cytoplasm with eosinophilic inclusion bodies. The cyst may rupture causing a foreign body granuloma ${ }^{[6]}$.

\section{Case proper}

Mr.AA23-yearold male patient presented with multiple warts on dorsum of right foot. Complaint started since 1 and half years. Nature of the warts were hard, painless with black discoloration at the base. Size of the warts was small during the initial stage, but it gradually increased. Took allopathic and ayurvedic treatment including external application for the complaint. But there was no improvement.

The patient has past history of exostosis on lower medial aspect right leg and painful corns on both sole. In his family history, father has been suffering from hypertension and diabetes, Mother has history of migraine and one of his cousins has warts on hand. Grandfather had asthmatic complaint and grandmother had thyroid complaint.

\section{Mental generals}

Reserved, Doing everything in a great hurry, Fear of darkness.

\section{Physical generals}

Thirst - Increased, prefer cold water

Desire- Sweets, Sour things

Thermal- Chilly

\section{Regionals}

Warts on right foot.

White scaly dandruff with hair fall.

\section{Totality of symptoms}

Reserved, doing everything in a great hurry, fear of darkness, thirsty, prefer cold water, desire for sweets and sour things, white scaly dandruff and warts on dorsum of foot.

\section{Repertorial Totality}

Mind- Reserved

Mind- Hurry, always in a

Mind- Fear- dark of

Generals -Food and drinks-sweets-desire

Generals -Food and drinks-sour things-desire

Stomach -Thirst-extreme

Head-Dandruff-white

Extremities - warts - lowerlimb -foot 


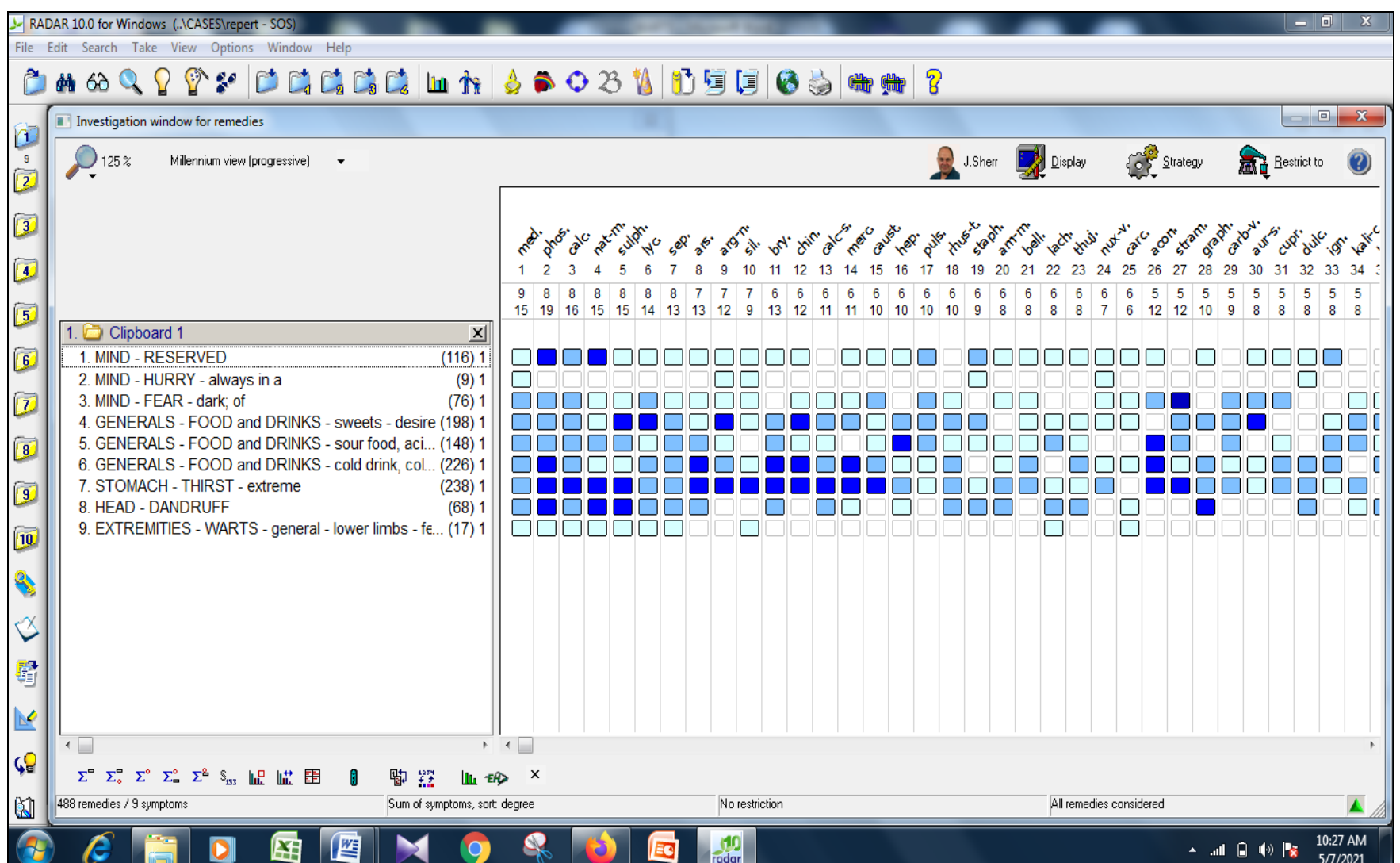

Chart 1: Repertorization Chart

\section{Repertorial Analysis.}

Medorrhinum-15/9

Phosph $-19 / 8$

Calc carb $-16 / 8$

Natrum mur-15/8

Sulph-15/8

Lyc- $14 / 8$

Sepia- $13 / 8$

Ars-13/7

\section{Analysis of the case}

After analysis of the case andrepertorisation with RADAR software, MEDORRHINUM10 $\mathrm{M}$ single dose was prescribed as similimum followed by placebo with improvement. There was a progressive reduction in the size of warts and completely disappear within three months (Fig.1 -3). Follow up of the case given in table -1 .

\section{Selection of medicine}

After repertorisation, MEDORRHINUM was selected as similimumbased onthe symptoms such asreserved, hurriedness for everything, fear of darkness,increased thirst,desires sweets, cold drinks and sourthings, dandruff on head and multiple warts on dorsum of right foot, also by considering predominant sycotic features in the past illness and family history.

Prescription: Medorrhinum 10M/1D on 14/01/21

Table 1: Prescription with follow-up

\begin{tabular}{|c|c|c|}
\hline Follow- up date & Indications for prescription & Medicine with dose \\
\hline $\begin{array}{c}\text { First } \\
\text { prescription on } \\
14 / 01 / 2021\end{array}$ & $\begin{array}{c}\text { Multiple warts on dorsum of the right foot (Figure-1) } \\
\text { Black discoloration around the warts Generals- Good. White scaly dandruff. }\end{array}$ & Medorrhinum 10m/1D \\
\hline $04 / 02 / 21$ & $\begin{array}{c}\text { Multiple warts on dorsum of the right foot same as before. Black discoloration around the warts } \\
\text { slightly reduced. Generals- Good. Dandruff persists. }\end{array}$ & Placebo \\
\hline $18 / 03 / 21$ & $\begin{array}{c}\text { Multiple warts on the dorsum of the right foot reduced in size. (Figure-2) } \\
\text { Black discoloration around the warts reduced. Generals- Good. Dandruff slightly reduced }\end{array}$ & Placebo \\
\hline $22 / 04 / 21$ & $\begin{array}{c}\text { Multiple warts on the dorsum of the right foot disappeared.(Fig.3) } \\
\text { Black discoloration around warts completely disappeared. Generals -Good. } \\
\text { Dandruff reduced. }\end{array}$ & Placebo \\
\hline
\end{tabular}




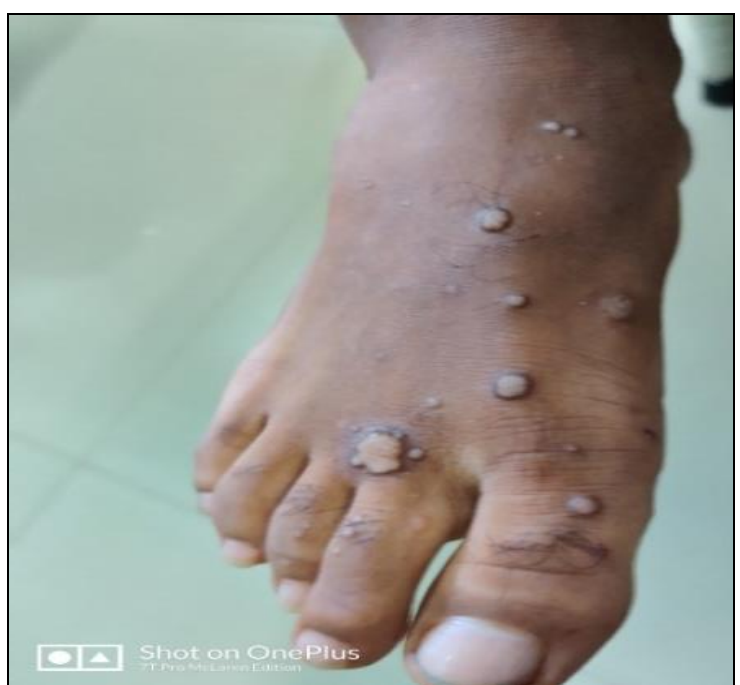

Fig 1: (Before treatment)

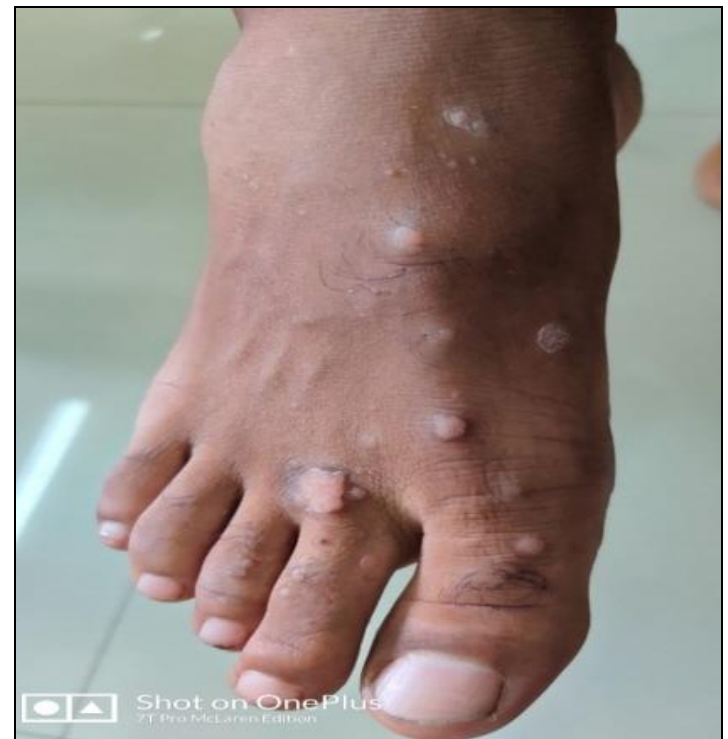

Fig 2: (During treatment)

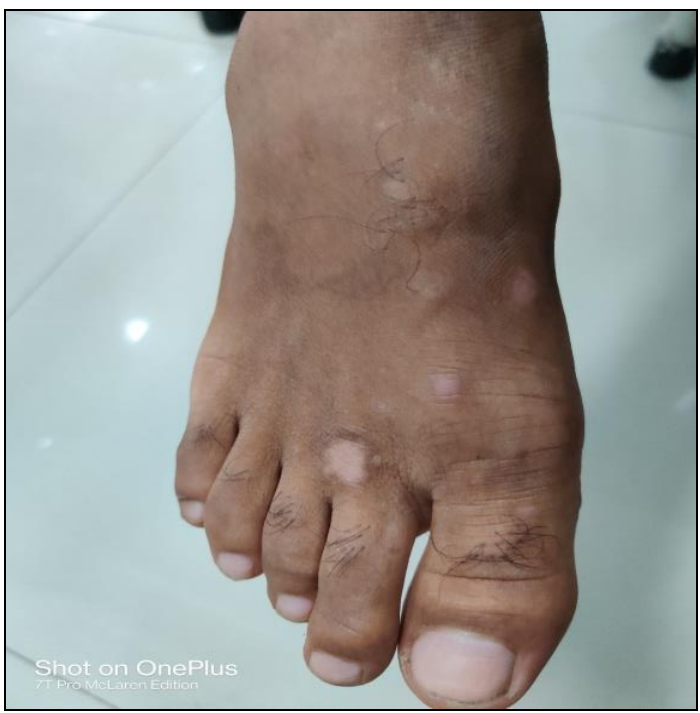

Fig 3: (After treatment)

\section{Discussion and Conclusion}

Homoeopathy is a wholistic system of medicine and treats the patient based on totality of symptoms. In this case, MEDORRHINUM $10 \mathrm{M}^{[7,8]}$ was prescribed as similimum ${ }^{[9]}$ by considering prominent mental symptoms such as reserved, hurriedness in activities, fear of darkness and physical generals like thirsty, desire cold drinks, desire sweets and sour food, multiple warts on dorsum of foot, thermally patient was chilly had predominantfeatures of sycotic miasm ${ }^{[10]}$ in past illness and family history. After the first prescription, there was a gradual reduction in size of warts and all the warts are completely disappeared within 3 months. This case shows the scope of homoeopathy in the management of warts.

\section{References}

1. Jabłonska S, Majewski S, Obalek S, Orth G. Cutaneous warts. Clinics in dermatology 1997;15(3):309-19.

2. Cohen PR, Hebert AA, Adler-Storthz K. Focal epithelial hyperplasia: Heckdisease. Pediatr Dermatol 1993;10(3):245-51.[Medicine]

3. Text book of medicine, KV Krishnadas. Reddy SR. Effect of homoeopathic medicine Lycopodium clavatum in urinary calculi. International Journal of Applied Research 2017;3(1):790-1. Fifth edition.

4. Kasper D, Fauci A, Longo DL, Braunwald E, Hauser SL, Jameson JL et al, Harrison's Principles of Internal Medicine. 14th Edition the Mcgraw-Hill Companies. 1998;1:1098,1099,1100

5. Sainani GS, Abraham, Dastur FD, Abraham P, Dastur Fd, Joshi Vr et al. A.P.I. Text Book of Medicine. 6th Edition. Association of Physicians of India Mumbai, Chapter: Infections of skin by HR Jerajani 1999.

6. Al Aboud AM, Nigam PK. Wart (Plantar, verruca vulgaris, verrucae) [updated 2020 Apr 28]. In: Stat pearls [Internet]. Treasure Island (FL): Stat pearls publishing 2020. Jan-Available from https://www.ncbi.nlm.nih.gov/books/NBK431047/

7. Vithoulkas G. Essence of Materia Medica.2nd Edn. New Delhi: B. Jain Publishers 2002. ISBN: 81-7021138-7

8. Clarke JH. A Dictionary of Practical Materia Medica. New Delhi: Indian Books \& Periodical publishers

9. Samuel Hahnemann. Organon of Medicine. Sixth edition. New Delhi, B. Jain Publishers.

10. Allen JH. Allen's The Chronic Miasms, Psora \& Sycosis Low Priced Edition: August-, B Jain Publishers Pvt. Ltd. New Delhi 2002. 